Bull. Fac. Agric., Cairo Univ., 68: 147-156(2017).

\title{
TOP CROSSES PERFORMANCE AND COMBINING ABILITY OF NEW YELLOW MAIZE INBRED LINES
}

(Received: 7.6.2017)

By

M. S. E. Sadek

Maize Department, Field Crops Research Institute, Agricultural Research Center, Giza, Egypt.

\begin{abstract}
Nineteen new yellow maize inbred lines $\left(\mathrm{S}_{3}\right)$ derived from different wide genetic base populations were top crossed with the two testers, commercial yellow inbred lines (Gz 639 and $\mathrm{Gm1021}$ ) at Gemmieza Agric. Res. Station during 2012 season. The obtained 38 top crosses along with the two checks (SC162 and SC168) were evaluated for grain yield, days to 50\% silking, plant height, ear position, at Gemmieza and Nubaria Agric. Res. Stations, ARC in 2013 growing season. Results showed that, mean squares due to lines and lines $\mathrm{x}$ tester interaction were highly significant for all studied traits. However, mean squares due to testers' were significant only for days to $50 \%$ silking and plant height. Highly significant differences were detected among locations for all studied traits. Lines $\mathrm{x}$ testers $\mathrm{x}$ location interaction were significant for plant height and ear position and highly significant for days to 50\% silking and grain yield. Additive gene action played the major role in the in heritance of days to $50 \%$ silking. While, non-additive gene action was responsible for inheritance of plant height, ear position and grain yield. The combined proportional contribution of lines was higher than that of testers. Inbred lines $\mathrm{Gm}$ 4005, Gm 4006, Gm 4015, Gm 4023 and 4029 possessed significantly positive GCA effects (desirable) towards high grain yield .The tester line; Gm 1021 was the best general combiner for earliness, shortness and low ear placement. While, tester line Gz 639 was the best combiner for grain yield. The best top crosses which had significant or highly significant and positive SCA effects towards high grain yield were Gm 4024 x Gm 1021, Gm 4027 x Gz 639, Gm 4008 x Gm 1021, Gm 4011 x Gm 1021, Gm 4010 x Gz 639, Gm 4026 x Gz 63, Gm 4025 x Gz 639 and Gm 4017 x Gm 1021. The highest yielding top cross was Gm 4015 x Gz 639 which had significant superiority for grain yield productivity over the highest check hybrid SC 162. And, top crosses Gm 4015 x Gz 639, Gm 4015 x Gm 1021 and Gm 4027 x Gz 639 which significantly and/or nonsignificantly out yielded the two check hybrids (SC 162 and SC 168). Three promising top crosses (Gm 4015 x Gm 1021 and Gm 4027 x Gz 639) should be tested in advanced trials for productivity and stability through the National Maize Breeding Program.
\end{abstract}

Key words: Maize, Line x tester, Gene action, Combining ability.

\section{INTRODUCTION}

Maize (Zea mays $\mathrm{L} . ; 2 \mathrm{n}=20$ ) is an important cereal crop world wide, belonging to the tribe Maydeae of the grass family Poaceae. It has great significance as human food, animal feed and as a source of hundreds of industrial products (Troyer, 2004).

One of the most important objectives of the National Maize Breeding Program in Egypt is increasing the yellow maize productivity to close the gap between the consumption and production. In order to achieve this goal, potentially suitable parents and superior combinations must be identified. Different breeding methods are employed for development of new inbred lines, where the most common hybrids with high yield productivity which are used for commercial production are derived from inbred lines.

In maize breeding program, combining ability is an effective tool which gives useful genetic information for the choice of parents in terms of their performance in series of crosses (Sprague and Tatum, 1942). The development of populations with high combining abilities has a fundamental role in the efficient use of heterosis (Vasal et al., 1992). Therefore, germplasm evaluation is a decisive aspect in maize breeding programs.

Line $\mathrm{x}$ tester procedure was suggested by 
Davis (1927) to evaluate the combining ability of inbred lines to determine the usefulness for hybrid development, deciding the relative ability of female and male lines to produce desirable hybrid combinations (Kempthorne 1957), provides information on genetic components and enables the breeder to choose appropriate breeding methods for hybrid variety or cultivar development programmes.

Combining ability effects in maize and heterotic classification of inbred lines has been extensively studied. Mihaljevic et al. (2005) reported that test cross performance of experimental lines is the prime selection criterion in hybrid breeding of maize. The International Maize and Wheat Improvement Center (CIMMYT) used measures of general combining ability and specific combining ability effects to establish heterotic patterns among its maize populations and pools (Vasal et al., 1992). Lines with greater specific combining ability effects could be used for hybrid development while those having greater general combining ability effects could be used effectively for synthetic cultivars development (Singh and Singh 1998, Mendoza et al., 2000, Konak et al., 2001 and Rahman et al., 2013). Information on combining ability effects helps the breeder in choosing the parents with high general major source of the total genetic variance responsible for the inheritance of grain yield in maize. However, Sadek et al., (2016) reported that additive gene effects were more important than non-additive gene in the inheritance of white maize for grain yield, days to 50\% silking, plant height, ear height and ear length.

The main objectives of this investigation were: (1) to evaluate 38 top crosses (19 lines x 2 testers) for grain yield and other traits, (2) to estimate general combining ability (GCA) effects for both lines and testers as well as specific combining ability (SCA) effects for crosses and (3) to identify the most superior line(s) and single crosses to be utilized in hybrid maize breeding program.

\section{MATERIALS AND METHODS}

This investigation was carried out at Gemmieza and Nubaria Agricultural Research Stations of the Agricultural Research Center, Egypt during 2012 and 2013 growing seasons. The used genetic materials were nineteen yellow $\mathrm{S}_{3}$ maize inbred lines derived from different wide genetic base populations through selection from segregating generations, in the disease nursery at Gemmeiza Research Station (the source of used genetic materials presented in Table 1).

In 2012 growing season, the 19 lines were top

Table (1): Source of yellow maize inbred lines and testers used in this study

\begin{tabular}{|l|l|}
\hline \multicolumn{1}{|c|}{ Inbred line } & \multicolumn{1}{|c|}{ Source } \\
\hline $\begin{array}{l}\text { Gm 4005, Gm 4006, Gm 4007, Gm 4008, Gm 4010, Gm 4011, Gm } \\
\text { 4015, Gm 4016, Gm 4017, Gm 4018 and Gm 4023. }\end{array}$ & Pool-22-622 \\
\hline $\begin{array}{l}\text { Gm 4024, Gm 4025, Gm 4026, Gm 4027, Gm 4028, Gm 4029, Gm } \\
\text { 4030and Gm 4031. }\end{array}$ & Pop-31-69 \\
\hline Gz 639 & Sd 62 X B73 \\
\hline Gm 1021 & $\begin{array}{l}\text { Improved sides yellow maize inbred } \\
\text { line 121 }\end{array}$ \\
\hline
\end{tabular}

combining ability and hybrids with high specific combining ability. In addition, general combining ability refers to the average performance of the genotype in a series of hybrid combinations and is a measure of additive gene action whereas; specific combining ability is the performance of a parent in a specific cross in relation to general combining ability (Sharief et al., 2009). Abd El Moula et al. (2010) revealed, that the presence of wide genetic diversity among each of the lines and testers has a contribution to the performance of top crosses. Soliman et al., (2007) reported that the magnitude of the dominance variance was the crossed with two testers, i.e. inbred lines Gz 639 and Gm1021 at Gemmeiza Res. Stn. In 2013 growing season, the resultant 38 top crosses along with two commercial check hybrids; i.e. SC162 and SC 168 were evaluated in a replicated yield trial conducted at two locations, Gemmeiza and Nubaria Agric. Res. Stns. The experimental design was a randomized complete block design with four replications. Plot size was one row, $6 \mathrm{~m}$ long and $80 \mathrm{~cm}$ wide. Planting was in hills spaced $25 \mathrm{~cm}$ along the row, at the rate of two kernels per hill and later thinned to one plant per hill to provide a plant population density of approximately 22000 plants faddan ${ }^{-1}$ (one faddan 
$=4200 \mathrm{~m}^{2}$ ). All cultural practices for maize production were applied as recommended. Data were recorded for the number of days to $50 \%$ silking, plant height $(\mathrm{cm})$, ear position $(\%)$ and grain yield (adjusted to $15.5 \%$ moisture content) was converted to ardab feddan ${ }^{-1}$ (one ardab $=140$ $\mathrm{kg}$ ). Analysis of variance was performed for separate locations and for the combined data across locations according to Steel and Torrie (1980). Combining ability effects were computed for all studied traits according to Kempthorne (1957) as outlined by Singh and Chaudhary (1985).

\section{RESULTS AND DISCUSSION}

\subsection{Analysis of variance}

Results of Mean squares presented in Table (2) revealed that, differences among crosses and lines were highly significant for all the studied traits across locations. However, testers mean squares were significant only for days to $50 \%$ silking and plant height. Mean squares due to lines $\mathrm{x}$ testers interaction were highly significant for all studied traits. These results indicated that, the line (L) females differed in their combining ability and performance of the crosses with each and Lines $\mathrm{x}$ Loc interaction were highly significant for all the studied traits. Testers $x$ Loc interaction were non-significant for all the studied traits, except for, grain yield which was highly significant. L $x$ T $x$ Loc interaction showed significance for plant height and ear position and highly significant for days to $50 \%$ silking and grain yield. Significant interaction of genotypes with locations may be attributed to the different ranking of genotypes from one location to another. Similar results were reported by Abd El Moula et al. (2010) who clarified that it is worthwhile to evaluate topcrosses under different environments (locations) especially for grain yield. This would help in deciding which hybrid can be recommended for certain environment. Also, Aly (2013) found significant triple interaction between locations, lines and testers for silking date, plant height, grain yield and yield per plant. However, El-Ghonemy (2015) revealed that line $\mathrm{x}$ tester $\mathrm{x}$ location mean squares were highly significant for grain yield only. The coefficient of variation (CV\%) for all traits was investigated to show the reliability of this experiment (Table 2).

Table (2): Mean squares for days to $50 \%$ silking, plant height (cm), ear postion (\%) and grain yield, combined across locations in 2013 season.

\begin{tabular}{|l|c|c|c|c|c|}
\hline \multirow{2}{*}{ S.O.V } & \multirow{2}{*}{ d.f. } & \multicolumn{4}{c|}{ Mean Square } \\
\cline { 3 - 6 } & & $\begin{array}{c}\text { Days to 50\% } \\
\text { silking }\end{array}$ & Plant height & $\begin{array}{c}\text { Ear position } \\
(\%)\end{array}$ & Grain yield \\
\hline Locations (Loc) & 1 & $59.951^{* *}$ & $22305.316^{* *}$ & $8547.842^{* *}$ & $9626.514^{* *}$ \\
\hline Rep/Loc & 6 & $21.520^{* *}$ & 239.331 & 5.322 & 8.606 \\
\hline Crosses (C) & 37 & $7.364^{* *}$ & $671.660^{* *}$ & $77.271^{* *}$ & $260.764^{* *}$ \\
\hline Line (L) & 18 & $8.640^{* *}$ & $388.087^{* *}$ & $91.620^{* *}$ & $206.035^{* *}$ \\
\hline Testers (T) & 1 & $6.082^{*}$ & $111.368^{*}$ & $36.961 \mathrm{~ns}$ & $1.694 \mathrm{~ns}$ \\
\hline L x T & 18 & $6.159^{* *}$ & $986.361^{* *}$ & $65.162^{* *}$ & $329.886^{* *}$ \\
\hline C x Loc & 37 & $2.600^{* *}$ & $215.545^{* *}$ & $16.863^{* *}$ & $3502.748^{* *}$ \\
\hline L x Loc & 18 & $2.138^{* *}$ & $241.141^{* *}$ & $17.53^{* *}$ & $1467.162^{* *}$ \\
\hline T x Loc & 1 & 0.082 & 3.803 & 21.052 & $134.237^{* *}$ \\
\hline L x T x Loc & 18 & $3.200^{* *}$ & $201.713^{*}$ & $15.963 *$ & $105.631^{* *}$ \\
\hline Pooled Error & 259 & 1.065 & 122.239 & 8.896 & 7.028 \\
\hline C.V\% & & 1.91 & 5.29 & 5.97 & 14.71 \\
\hline
\end{tabular}

*, ** Significant at 0.05 and 0.01 levels of probability, respectively.

of the tester (T) males. Similar results were reported by Abd El-Azeem et al. (2004), Abd El Ghany et al. (2008), Aly et al. (2011), Ali et al. (2012), Aly and Khalil (2013), El-Ghonemy (2015), Barh et al. (2015) and Abo Yousef et al. (2016). In addition, the Loc $\mathrm{x}$ crosses interaction

\subsection{Genetic components}

Estimates of genetic variance components for all studied traits combined across the two locations and their interaction are presented in Table (3). The results showed that, estimates of 
$\delta^{2} \mathrm{~L}$ were higher in magnitude than those of $\delta^{2} \mathrm{~T}$ for days to $50 \%$ silking and ear position $\%$, , indicating that most of the total GCA variances were due the inbred lines and the contribution of the lines were higher than the contribution of the testers for these traits. General combining ability variance component ( $\delta^{2} \mathrm{GCA}$ ) was larger than $\delta^{2}$ SCA for days to $50 \%$ silking, indicating that the additive gene action played the major role in the inheritance of this trait. However, $\delta^{2} \mathrm{SCA}$ was larger than $\delta^{2} \mathrm{GCA}$ for the other studied traits (plant height, ear position $\%$, and grain yield) indicating that non-additive gene action was more important than additive gene action in the inheritance for these traits.

In this respect, Wright et al. (1971) reported that in maize non-additive genetic variance is more often evident in controlling the inheritance of traits than additive components. Similar results confirmed the role of non-additive gene action for grain yield has been reported earlier by Vijayabharathi et al. (2009) and Kanagarasu et al. (2010). Also, Barh et al. (2015) suggested that, the non-additive genetic variance is the major reason towards a hybrid performance for all studied characters. This means that nonadditive action is important for the hybrid performance. However pervious results are in partial agreement with those reported by Aly and Khalil (2013), who found that additive gene action played a major role in the inheritance of silking date and grain yield. Aly et al. (2011) indicated that non- additive gene action was important than additive in the inheritance for silking date, plant height and ear position \%. On the contrary, Sadek et al. (2016) found that additive gene effects were more important than non-additive effects in the inheritance of days to $50 \%$ silking, plant height, ear height and grain yield. That might be due to different breeding materials or environmental variation for each study. The genetic components for a certain trait would depend mainly on the environmental fluctuations under which the breeding genotypes will be tested (Kamara et al., 2014)

Results in Table (3) revealed that the variance of $\delta^{2} \mathrm{SCA} \times$ location interaction was higher than the variance of $\delta^{2}$ GCA $x$ location for all studied traits. These results indicated that the non-additive type of gene action was more affected by environmental conditions than additive effects. Similar results were reported by Aly et al. (2011), EL-Hosary and Elgammaal (2013) and Sadek et al. (2016). The combined proportional contributions of inbred lines for all studied traits were higher than those of testers. The great contribution of lines in the total variation for studied traits is an indication of maternal influence of the inbred lines on the studied traits. Similar results were found by other researchers; Abd El-Ghany et al. (2008), Uddin et al. (2008), Hefny (2010) and Abo Yousef et al. (2016).

Table (3): Estimates of genetic variance components for all the studied traits combined across locations.

\begin{tabular}{|c|c|c|c|c|}
\hline Variance & Days to $50 \%$ silking & Plant height & Ear position \% & Grain yield \\
\hline$\delta^{2} \mathrm{~L}$ & 0.22 & ---- & 1.56 & ---- \\
\hline$\delta^{2} \mathrm{~T}$ & 0.02 & $\begin{array}{ll}--- \\
---\end{array}$ & ---- & $\begin{array}{ll}--- \\
---\end{array}$ \\
\hline$\delta^{2} \mathrm{GCA}$ & 3.46 & ---- & 3.59 & ---- \\
\hline$\delta^{2} \mathrm{SCA}$ & 0.37 & 98.08 & 6.15 & 28.03 \\
\hline$\delta^{2} \mathrm{Lx}$ loc & ---- & 4.93 & 0.20 & 170.19 \\
\hline$\delta^{2} \mathrm{~T}$ x loc & --- & --- & 0.07 & 0.38 \\
\hline$\delta^{2}$ GCA x Loc & ---- & 4.93 & 0.20 & 170.19 \\
\hline$\delta^{2}$ SCA x Loc. & 0.53 & 19.87 & 1.77 & 24.65 \\
\hline Contribution of lines $\%$ & 57.08 & 28.11 & 57.68 & 38.44 \\
\hline Contribution of testers $\%$ & 2.23 & 0.45 & 1.29 & 0.02 \\
\hline Contribution of L x T\% & 40.69 & 71.44 & 41.02 & 61.54 \\
\hline
\end{tabular}

Variance estimates proceeded by negative sign(----) is considered zero (Robinson et al.,1955). T= testers $\mathrm{L}=$ lines, loc $=$ locations. 


\subsection{Mean performance}

Mean performance of the 38 top crosses along with the check hybrids for days to $50 \%$ silking, plant height, ear position and grain yield is presented in Table (4). For number of days to $50 \%$ silking, all the evaluated top crosses were significantly earlier than the earliest check hybrid SC 162. Moreover, the earliest crosses were Gm 4007 x Gm 1021, Gm 4015 x Gz 639, Gm 4015 x Gm 1021, Gm 4016 x Gz 639, Gm 4018 x Gz 639, Gm 4023 x Gz 639 and Gm 4027x Gm 1021. With respect of plant height, all top crosses involving tester line Gz 639 were highly significant shorter than the check hybrid SC 162, except Gm 4018 x Gz 639, Gm 4031 x Gz 639, Gm 4023 x Gz 639 and Gm 4027 x Gz 639. And, for top crosses involving $\mathrm{Gm} \mathrm{1021}$, all single crosses were highly significant shorter than the check hybrid SC 162 except, Gm 4006 x Gm 1021, Gm 4010 x Gm 1021, Gm 4017 x Gm 1021 and Gm 4030 x Gm 1021. However, the shortest single cross Gm 4027 x Gm 1021 $(198 \mathrm{~cm}$.) was highly significant shorter than the shortest single hybrid SC 168.
Regarding ear position, results in Table (3) showed that, all top crosses had significantly lower ear placement than the check SC 168 except Gm 4028 x Gz 639, Gm 4031 x Gz 639 and $\mathrm{Gm} 4030$ x $\mathrm{Gm}$ 1021. The lowest ear placement cross was exhibited by Gm 4027 x Gm 1021 (46\%), while the highest value was (59 \%) for the cross $\mathrm{Gm} 4028 \times \mathrm{Gz} 639$. In addition there were 8 crosses with values ranged from $46 \%$ to $50 \%$, exhibiting highly significant lower ear placement than the lowest check SC 162.

Regarding grain yield $\left(\operatorname{ard} \mathrm{fed}^{-1}\right)$, results presented in Table (4) showed that, the highest yielding top cross was $\mathrm{Gm} 4015$ x Gz 639 which had significant superiority for grain yield productivity over the highest check hybrid SC 162. Moreover, top crosses Gm 4015 x Gm 1021 and Gm 4027 x Gz 639 significantly out yielded the check hybrid SC 168. In addition, these crosses also were characterized by early maturity. In general, the average performance of crosses of the two tester lines was approximately equal. The crosses involving tester line Gz 639,

Table (4): Average performance of 38 top crosses for days to $50 \%$ silking, plant height, ear position (\%) and grain yield (ard fed-1) combined across locations in 2013 season.

\begin{tabular}{|c|c|c|c|c|c|c|c|c|}
\hline \multirow{2}{*}{ Lines } & \multicolumn{2}{|c|}{ Days to $50 \%$ silking } & \multicolumn{2}{|c|}{ Plant height (cm) } & \multicolumn{2}{|c|}{ Ear position \% } & \multicolumn{2}{|c|}{ Grain yield ard/fed } \\
\hline & Gz639 & Gm1021 & Gz639 & Gm1021 & Gz639 & Gm1021 & Gz639 & Gm1021 \\
\hline Gm 4005 & 59 & 59 & 223 & 215 & 49 & 52 & 33.02 & 32.63 \\
\hline Gm 4006 & 61 & 59 & 211 & 230 & 56 & 54 & 30.96 & 32.55 \\
\hline Gm 4007 & 59 & 58 & 213 & 226 & 47 & 53 & 30.86 & 32.27 \\
\hline Gm 4008 & 61 & 59 & 226 & 224 & 56 & 54 & 21.40 & 34.44 \\
\hline Gm 4010 & 59 & 60 & 223 & 230 & 54 & 52 & 29.74 & 20.03 \\
\hline Gm 4011 & 59 & 59 & 217 & 226 & 58 & 58 & 23.65 & 34.81 \\
\hline Gm 4015 & 58 & 58 & 226 & 216 & 55 & 50 & 40.63 & 38.32 \\
\hline Gm 4016 & 58 & 59 & 217 & 218 & 50 & 53 & 29.45 & 30.44 \\
\hline Gm 4017 & 59 & 59 & 227 & 227 & 56 & 55 & 25.17 & 31.19 \\
\hline Gm 4018 & 58 & 59 & 238 & 221 & 54 & 49 & 30.85 & 25.48 \\
\hline Gm 4023 & 58 & 59 & 230 & 222 & 56 & 54 & 35.83 & 32.74 \\
\hline Gm 4024 & 61 & 59 & 209 & 219 & 49 & 53 & 23.34 & 34.83 \\
\hline Gm 4025 & 60 & 60 & 226 & 210 & 53 & 51 & 34.48 & 27.54 \\
\hline Gm 4026 & 61 & 59 & 218 & 210 & 53 & 55 & 31.30 & 23.49 \\
\hline Gm 4027 & 59 & 58 & 228 & 198 & 52 & 46 & 36.94 & 29.65 \\
\hline Gm 4028 & 59 & 61 & 218 & 222 & 59 & 56 & 32.90 & 30.56 \\
\hline Gm 4029 & 59 & 59 & 213 & 217 & 51 & 54 & 33.33 & 32.46 \\
\hline Gm 4030 & 59 & 60 & 206 & 241 & 53 & 57 & 30.61 & 30.87 \\
\hline Gm 4031 & 62 & 60 & 232 & 205 & 57 & 47 & 29.19 & 27.58 \\
\hline Mean & $\mathbf{5 9 . 4 2}$ & 59.16 & 221.11 & 219.84 & 53.58 & 52.79 & 30.72 & 30.63 \\
\hline \multicolumn{9}{|l|}{ Checks } \\
\hline SC162 & \multicolumn{2}{|c|}{64} & \multicolumn{2}{|c|}{241} & \multicolumn{2}{|c|}{56} & \multicolumn{2}{|c|}{36.78} \\
\hline SC168 & \multicolumn{2}{|c|}{65} & \multicolumn{2}{|c|}{215} & \multicolumn{2}{|c|}{59} & \multicolumn{2}{|c|}{33.35} \\
\hline LSD0.05 & \multicolumn{2}{|c|}{1.01} & \multicolumn{2}{|c|}{10.83} & \multicolumn{2}{|c|}{2.92} & \multicolumn{2}{|c|}{2.60} \\
\hline LSD0.01 & \multicolumn{2}{|c|}{1.33} & \multicolumn{2}{|c|}{14.24} & \multicolumn{2}{|c|}{5.73} & \multicolumn{2}{|c|}{3.43} \\
\hline
\end{tabular}


i.e. $\mathrm{Gm} 4023$ x Gz 639 and $\mathrm{Gm} 4025$ x Gz 639 had grain yield productivity (35.38 and 34.48 $\operatorname{ard} / \mathrm{fed}$, respectively) with no significant differences compared to the check hybrid SC 162 , followed by seven crosses which produced grain yield ranged from 33.33 to $30.86 \mathrm{ard} / \mathrm{fed}$ with no significant differences compared with the check hybrid SC 168 . However, the crosses involving tester line $\mathrm{Gm} \mathrm{1021}$, i.e. $\mathrm{Gm} 4024 \mathrm{x}$ Gm 1021, Gm 4011 x Gm 1021 and Gm 4008 x Gm 1021 gave grain yield productivity ranged from 34.83 to 34.44 ard/fed with no significant differences compared to the check hybrid SC 162 , followed by seven crosses which gave grain yield productivity with no significant differences compared to the check hybrid SC 168.

\subsection{General (GCA) and specific (SCA) combining ability effects}

Results in Table (5) showed the general combining ability (GCA) effects for nineteen inbred lines and two testers as combined across two locations. Inbred lines Gm 4007, Gm 4015, Gm 4016 and $\mathrm{Gm} 4027$ had negative and significant GCA effects (desirable) towards earliness for days to 50\%silking. However, inbred lines Gm 4006, Gm 4008, Gm 4028 and Gm 4031 had significantly positive GCA effects (undesirable) towards lateness. For plant height, Gm 4024, Gm 4026, Gm 4027 and Gm 4029 had significantly negative GCA effects towards shortness. On the other hand, Gm 4010, Gm 4017, and Gm 4018 across locations exhibited significantly positive GCA effects towards tallness. Inbred lines $\mathrm{Gm} \mathrm{4005,} \mathrm{Gm} \mathrm{4007,} \mathrm{Gm}$ 4016, Gm. 4018, Gm 4024, Gm 4027 and Gm 4031 had significant negative GCA effects towards low ear placement (desirable). Whereas, inbred lines $\mathrm{Gm}$ 4006, Gm 4008, Gm 4011, Gm 4017, Gm 4023, Gm 4028 and $\mathrm{Gm} 4030$ exhibited significant and positive GCA effects towards high ear placement (undesirable). With respect to grain yield, the inbred lines Gm 4015, Gm 4023,Gm 4029, Gm 4005 and Gm 4006 possessed significantly positive GCA effects (desirable) towards high grain yield. In contrast, inbred lines $\mathrm{Gm}$ 4010, Gm 4024, Gm 4026 and Gm 4027 across locations possessed significantly negative GCA effects (undesirable) towards low grain yield.The obtained results in Table (5) showed that, both testers were insignificant in GCA for all studied traits.

Estimates of specific combining ability (SCA) effects of 38 topcrosses for all the studied traits as a combined across two locations were presented in Table (6). The results showed that the best SCA effects towards earliness were obtained by top crosses; Gm 4028 x Gz 639, Gm 4024 x Gm 1021, Gm 4016 x Gz 639 and Gm 4008 x Gm 1021 which had high and/or significant negative SCA effects. However, four crosses; Gm 4028 x Gm 1021, Gm 4024 x Gz 639, Gm 4016 x Gm 1021 and Gm 4008 x Gz 639 had positive values of SCA (undesirable) towards late maturity. For plant height, four top crosses possessed either significant or highly significant negative SCA effects towards shortness. These crosses were $\mathrm{Gm} 4030 \mathrm{x} \mathrm{Gz}$ 639, Gm 4031 x Gm 1021, Gm 4027 x Gm 1021 and $\mathrm{Gm} 4006$ x Gz 639. While, top crosses $\mathrm{Gm}$ 4030 x Gm1021, Gm 4031 x Gz 639, Gm 4027 x Gz 639 and Gm 4006 x Gm 1021 had significant and positive SCA effects towards tallness (undesirable). For ear position, five topcrosses, (Gm 4031 x Gm 1021, Gm 4007 x Gz 639, Gm 4030 x Gz 639, Gm 4027 x Gm. 1021 and Gm 4015 x Gm 2021) had significant and negative SCA effects towards low ear placement. On the contrary, the five crosses $(4031$ x Gz 639, Gm 4007 x Gm 1021, Gm 4030 x Gm 1021, Gm 4027 x Gz 639 and $\mathrm{Gm} 4015$ x Gz 639) had significant and positive SCA effects towards high ear placement. In respect to grain yield, results showed that, the best topcrosses which had significant or highly significant and positive SCA effects towards high yield were $\mathrm{Gm} 4024 \mathrm{x}$ Gm 1021, Gm 4027 x Gz 639, Gm 4008 x Gm 1021, Gm 4011 x Gm 1021, Gm 4010 x Gz 639, Gm 4026 x Gz 63, Gm 4025 x Gz 639 and Gm 4017 x Gm 1021. In the contrast, the crosses Gm 4024 x Gz 639, Gm 4027 x Gm 1021, Gm 4008 x Gz 639, Gm 4011 x Gz 639, Gm 4010 x Gm 1021, Gm 4026 x Gm 1021, Gm 4025 x Gm 1021 and $\mathrm{Gm} 4017$ x Gz 639 possessed significant or highly significant and negative SCA effects for grain yield.

Many authors also reported higher specific combining ability and general combining ability for different inbred lines in maize. Konak et al. (2001) reported that, lines with greater specific combining ability effects could be used for hybrid development while those having greater general combining ability could be used effectively for synthetic cultivars development. Moreover, Abd El-Ghany et al. (2008), Abd ElMoula et al. (2010), El-Ghonemy (2015) and Sadek et al. (2016) determined the superior inbred lines as good tersters and desirable specific combining ability of topcrosses as 


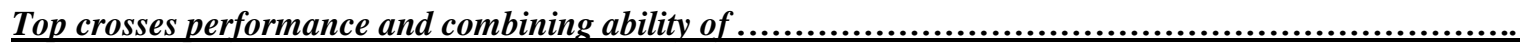

Table (5): Estimates of general combining ability effects for days to $50 \%$ silking, plant height, ear position, and grain yield combined over locations, in 2013 growing season.

\begin{tabular}{|c|c|c|c|c|}
\hline Lines & Days to $50 \%$ silking & Plant height & Ear position & Grain yield \\
\hline Gm 4005 & -0.35 & -1.25 & $-2.40 * *$ & $2.77 *$ \\
\hline Gm 4006 & $0.84 * *$ & 0.03 & $1.73 *$ & $1.70 *$ \\
\hline Gm 4007 & $-0.91 * *$ & -1.31 & $-2.90 * *$ & 1.51 \\
\hline $\mathrm{Gm} 4008$ & $0.59 *$ & 4.69 & $1.54 *$ & -2.14 \\
\hline $\mathrm{Gm} 4010$ & 0.15 & $6.19 *$ & -0.52 & $-5.17 * *$ \\
\hline Gm 4011 & -0.04 & 1.32 & $4.79 * *$ & -0.82 \\
\hline Gm 4015 & $-1.48^{* * *}$ & 0.32 & -1.02 & $9.42 * *$ \\
\hline $\mathrm{Gm} 4016$ & $-0.91 * *$ & -2.87 & $-1.65^{*}$ & -0.11 \\
\hline $\mathrm{Gm} 4017$ & -0.41 & $6.88 *$ & $2.04 * *$ & -1.88 \\
\hline Gm 4018 & -0.48 & $9.44 * *$ & $-1.71 *$ & -1.90 \\
\hline $\mathrm{Gm} 4023$ & -0.23 & 5.19 & $2.10^{* * *}$ & $4.22 * *$ \\
\hline $\mathrm{Gm} 4024$ & 0.52 & $-6.68 * *$ & $-1.90 *$ & $-6.55 * *$ \\
\hline $\mathrm{Gm} 4025$ & 0.40 & -2.62 & -1.02 & 0.95 \\
\hline $\mathrm{Gm} 4026$ & 0.52 & $-6.56^{*}$ & 1.10 & $-2.66^{*}$ \\
\hline $\mathrm{Gm} 4027$ & $-0.79 * *$ & $-7.68 * *$ & $-4.02 * *$ & $-2.87 *$ \\
\hline $\mathrm{Gm} 4028$ & $0.65^{*}$ & -0.56 & $4.10^{* *}$ & 1.67 \\
\hline Gm 4029 & 0.02 & $-5.81 *$ & -0.52 & $2.84 *$ \\
\hline Gm4030 & 0.40 & 3.00 & $1.85 *$ & 0.68 \\
\hline Gm4031 & $1.52 * *$ & -1.68 & $-1.58 *$ & -1.67 \\
\hline SE gi Lines & 0.28 & 2.91 & 0.79 & 1.11 \\
\hline SE (gi-gj) & 0.40 & 4.12 & 1.12 & 1.56 \\
\hline \multicolumn{5}{|l|}{ Testers } \\
\hline Gz 639 & 0.14 & 0.61 & 0.35 & 0.07 \\
\hline Gm1021 & -0.14 & -0.61 & -0.35 & -0.07 \\
\hline SE gi testers & 0.09 & 0.95 & 0.26 & 0.36 \\
\hline SE (gi-gj) & 0.13 & 1.34 & 0.36 & 0.51 \\
\hline
\end{tabular}

*** Significant at 0.05 and 0.01 levels of probability, respectively.

Table (6): Estimates of specific combining ability effects for days to $50 \%$ silking, plant height, ear position and grain yield combined across locations in 2013 season.

\begin{tabular}{|c|c|c|c|c|c|c|c|c|}
\hline \multirow{2}{*}{ Lines } & \multicolumn{2}{|c|}{ Days to $50 \%$ silking } & \multicolumn{2}{|c|}{ Plant height } & \multicolumn{2}{|c|}{ Ear position } & \multicolumn{2}{|c|}{ Grain yield ard/fed } \\
\hline & Gz639 & Gm1021 & Gz639 & Gm1021 & Gz639 & Gm1021 & Gz639 & Gm1021 \\
\hline Gm 4005 & -0.27 & 0.27 & 3.08 & -3.08 & -1.66 & 1.66 & 0.12 & -0.12 \\
\hline Gm 4006 & 0.67 & -0.67 & $-10.29 *$ & $10.29 *$ & 0.46 & -0.46 & -0.87 & 0.87 \\
\hline Gm 4007 & 0.55 & -0.55 & -7.11 & 7.11 & $-3.16^{*}$ & $3.16^{*}$ & -0.78 & 0.78 \\
\hline $\mathrm{Gm} 4008$ & $0.80 *$ & $-0.80 *$ & 0.39 & -0.39 & 0.65 & -0.65 & $-6.60 * *$ & $6.60 * *$ \\
\hline $\mathrm{Gm} 4010$ & -0.64 & 0.64 & -3.73 & 3.73 & 0.59 & -0.59 & $4.78 * *$ & $-4.78 * *$ \\
\hline Gm 4011 & -0.20 & 0.20 & -4.98 & 4.98 & -0.72 & 0.72 & $-5.65^{*}$ & $5.65^{*}$ \\
\hline Gm 4015 & -0.39 & 0.39 & 4.39 & -4.39 & $2.21 *$ & $-2.21 *$ & 1.08 & -1.08 \\
\hline $\mathrm{Gm} 4016$ & $-0.83 *$ & $0.83^{*}$ & -1.54 & 1.54 & -1.54 & 1.54 & -0.57 & 0.57 \\
\hline $\mathrm{Gm} 4017$ & -0.08 & 0.08 & -0.67 & 0.67 & 0.28 & -0.28 & $-3.08 *$ & $3.08 *$ \\
\hline Gm 4018 & -0.39 & 0.39 & 7.89 & -7.89 & 1.90 & -1.90 & 2.61 & -2.61 \\
\hline $\mathrm{Gm} 4023$ & -0.14 & 0.14 & 3.39 & -3.39 & 0.59 & -0.59 & 1.47 & -1.47 \\
\hline $\mathrm{Gm} 4024$ & $0.98 *$ & $-0.98 *$ & -5.73 & 5.73 & -2.16 & 2.16 & $-11.39 * *$ & $11.39 * *$ \\
\hline Gm 4025 & -0.27 & 0.27 & 7.21 & -7.21 & 0.34 & -0.34 & $3.39 *$ & $-3.39 *$ \\
\hline $\mathrm{Gm} 4026$ & 0.73 & -0.73 & 3.52 & -3.52 & -1.54 & 1.54 & $3.83 *$ & $-3.83 *$ \\
\hline $\mathrm{Gm} 4027$ & 0.55 & -0.55 & $14.27 *$ & $-14.27 *$ & $2.46^{*}$ & $-2.46^{*}$ & $9.67 * *$ & $-9.67 * *$ \\
\hline Gm 4028 & $-1.27 * *$ & $1.27 * *$ & -2.73 & 2.73 & 1.34 & -1.34 & 1.10 & -1.10 \\
\hline Gm 4029 & -0.02 & 0.02 & -2.61 & 2.61 & -2.16 & 2.16 & 0.36 & -0.36 \\
\hline $\mathrm{Gm} 4030$ & -0.39 & 0.39 & $-17.92 * *$ & $17.92 * *$ & $-2.54 *$ & $2.54 *$ & -0.21 & 0.21 \\
\hline Gm 4031 & 0.61 & -0.61 & $13.14 *$ & $-13.14 *$ & $4.65 * *$ & $-4.65 * *$ & 0.73 & -0.73 \\
\hline SE. $S_{i j}$ & \multicolumn{2}{|c|}{0.40} & \multicolumn{2}{|c|}{4.12} & \multicolumn{2}{|c|}{1.12} & \multicolumn{2}{|c|}{1.56} \\
\hline $\operatorname{SE}\left(\mathrm{S}_{\mathrm{ij}} \mathrm{S}_{\mathrm{kl}}\right)$ & \multicolumn{2}{|c|}{0.57} & \multicolumn{2}{|c|}{5.82} & \multicolumn{2}{|c|}{1.58} & \multicolumn{2}{|c|}{1.87} \\
\hline $\operatorname{SE}\left(S_{\mathrm{ij}} \mathrm{S}_{\mathrm{ik}}\right)$ & \multicolumn{2}{|c|}{0.73} & \multicolumn{2}{|c|}{7.82} & \multicolumn{2}{|c|}{2.12} & \multicolumn{2}{|c|}{2.21} \\
\hline
\end{tabular}

*, ** Significant at 0.05 and 0.01 levels of probability, respectively 
promising hybrids in their results.

It could be concluded that, the promising inbred lines Gm 4015, Gm 4023, Gm 4029, Gm 4005, and Gm 4006 which possessed the best GCA effects for grain yield should be utilized to improve yellow maize hybrids productivity. The best general combiner of tester line was Gz 639 for high yielding ability. However, the inbred line Gm1021 may be good combiner for earliness, shortness and low ear placement. Moreover, the present findings suggested that the most promising crosses were $\mathrm{Gm} 4015 \mathrm{x} \mathrm{Gz}$ 639, Gm 4015 x Gm 1021 and Gm 4027 x Gz 639 which outyielded the commercial checks SC 162 and SC 168 and were characterized by early maturity. Accordingly, they should be further tested for the possibility of commercial release as new yellow maize hybrids.

\section{REFERENCES}

Abd El-Azeem M. E., Mahmoud A. A. and Atia A. A. M. (2004). Combining ability analysis of yellow maize inbred lines. Egypt. J. Pl. Breed. (8): 239-254.

Abd El-Ghany H. M., Osman M. M. and Sadek M. E. (2008). Evaluation of some white maize inbred lines for combining ability based on top-crosses. J. Agric. Sci. Mansoura Univ., 33 (3) 1747-1760.

Abd El-Moula M. A., El- Sayed T.A. and Sadek Moshera S. E. (2010). Utilization of narrow base testers to estimate combining ability of maize inbred lines. Egypt. J. Agric. Res., 88 (1), 47-62.

Abo Yousef H. A., Gamea H. A. A. and Sadek Moshera S.E. (2016). Evaluation of some new white maize top crosses for yield and some other traits. Alex. J. Agric. Sci., 61: 409-418.

Ali F., Shah I. A., Rahman H.U., Noor M., Durrisahwar Khan M. Y., Ihteram Ullah and Yan J. (2012). Heterosis for yield and agronomic attributes in diverse maize germplasm. Aus. J. Crop sci. 6 (3) 455462.

Aly R. S. H. (2013). Relationship between combining ability of grain yield and yield components for some newly yellow maize inbred lines via line $\mathrm{x}$ tester analysis. Alex. J. Agric. Res., 58 (2)115-124.

Aly R. S. H., Metwali E. M. R. and Mousa S.T.M. (2011). Combining ability of maize (Zea mays L) Inbred lines for grain yield and some agronomic traits using topcross mating design. Global J. Mol. Sci.,1: $1-8$

Aly R. S. H. and Khalil M. A. G. (2013). Combining ability for sixteen promising white maize inbred lines for grain yield and yield component traits. Egypt. J. pl. Breed. 17: 143-160.

Barh A., Singh N.K., Verma S.S., Jaiswal J. P. and Shukla P.S. (2015). Combining ability analysis and nature of gene action for grain yield in Maize hybrids. Int'l. J. Environ. and Agric. Res., 1 (8) 1-5

Davis R.L. (1927). Report of the plant breeding. Ann. Rep. Puerto Rico Agric. Exp., Stat., P: $14-15$.

El-Ghonemy M. A. M. (2015). Combining ability of new yellow maize inbred lines using Top cross method. Egypt. J. pl. Breed., 19: 903-915.

El-Hosary A. A. A. and Elgammaal A. A. (2013). Utilization of line $x$ tester model for evaluating the combining ability of some new white maize inbred lines. Egypt. J. Pl. Breed., 17 (1): 79 - 92.

Hefny M. (2010). Genetic control of flowering traits, yield and its components in maize (Zea mays L.) at different sowing dates. Asian J. Crop Sci. (2): 236-249.

Kamara M. M., El-Degwy I. S. and Koyama H. (2014). Estimation combining ability of some maize inbred lines using line $\times$ tester mating design under two nitrogen levels. Aust. J. Crop Sci., 8 (9):1336-1342

Kanagarasu S., Nallathambi G. and Ganesan K. N. (2010). Combining ability analysis for yield and its component traits in maize (Zea mays L.). Electronic J. Pl. Breed., 1 (4), 915-920.

Kempthorne O. (1957). An Introduction to Genetic Statistics. John Wiley and Sons Inc., NY,USA.

Konak C., Unay A., Serter E. and Basal H. (2001). Estimation of combining ability effects, heterosis and heterobeltios using line $\times$ tester method in maize. Turk. J. Field Crops., 4 (1): 1-9.

Mendoza M., Oyervides A. and Lopez A. (2000). New maize cultivars with agronomic potential for the humid tropics. Agronomia, Mesoamericana, 11 (I): 8388.

Mihaljevic R., Schön C. C., Utz H. F. and Melchinger A. E. (2005). "Correlations and QTL correspondence between line per 
se and testcross performance for agronomic traits in four population of European maize." Crop Science, 45 (1): 114-122.

Rahman H., Ali A., Shah Z., Iqbal M., Noor M. and Amanullah (2013). Line x Tester analysis for grain yield and yield related traits in maize variety sarhad-white. Pak. J. Bot., 45: 383-387.

Sadek M. S. E., Abd El Mottalb A. A. and Gamea H. A. A. (2016). Estimation of combining ability for some promising white maize inbred lines through line $\mathrm{x}$ tester mating design under different locations. Egypt. J. Pl. Breed.,(Special Issue), 20: 175- 191.

Sharief A. E., El-Kalla S.E., Gado H. E., AboYousef H. A. E (2009). Heterosis in yellow maize. Aust J Crop Sci., 3: 146154

Soliman F.H.S., Shafay SH. A., El-Agamy A. I. and Mostafa M. A. (2007). Inheritance of grain yield and oil content in new maize high oil single crosses. Conf. Egypt. J. Pl. Breed., 11 (2): 507-530.

Singh D. N. and Singh I. S. (1998). Line $\times$ tester analysis in maize. J. Res. Birsa Agric. Univ., 10(2): 177-182.

Singh R. K. and Chaudhary B. D. (1985). Biometrical methods in quantitative genetic analysis. Kalyani Publishers. New Delhi, India, $3^{\text {rd }}$ Ed.
Sprague G. F. and Tatum L. A. (1942). General vs. specific combining ability in single crosses of corn. J. Am. Agron., 34: 923932.

Steel R. G. and Torrie J. H. (1980). Principles and Procedures of Statistics. McGrow Hill Book., New York, USA.

Troyer A. F. (2004). "Background of US Hybrid Corn II." Crop Science, 44(2): 370-380

Uddin M. S., Amiruzzaman M., Bagum S. A., Hakim M. A. and Ali M. R. (2008). combining ability and heterosis in maize (Zea mays, L.). Bangladesh J. Genet. Pl. Breed., 21(1): 21-28.

Vasal S. K., Srinivasan G., Crossa J. and Beck D. L. (1992). Heterosis and combining ability of CIMMYT's subtropical and temperate early-maturity maize germplasm. Crop Sci., 32(4): 884-890.

Vijayabharathi A., Anandakumar C. R. and Gnanamalar R.P. (2009). Combining ability analysis for yield and its components in popcorn (Zea mays var. everta Sturt.). Electronic J. Pl. Breed., 1: 28-32.

Wright J. A., Hallaeur A. R., Penny L. H. and Eberhart S.A. (1971). Estimating genetic variance in maize by use of single and three-way crosses among unselected inbred lines. Crop Sci., 11:690-697.

$$
\begin{aligned}
& \text { الهجن القمية والقدرة على التآلف في سلالات صفراء جديدة من الذرة الشامية }
\end{aligned}
$$

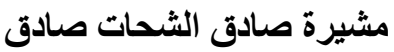

$$
\begin{aligned}
& \text { قسم بحوث الذرة الثامية ـ معهد بحوث المحاصيل الحقلية ـ مركز البحوث الزر اعية ـ الجيزة ـ مصر }
\end{aligned}
$$

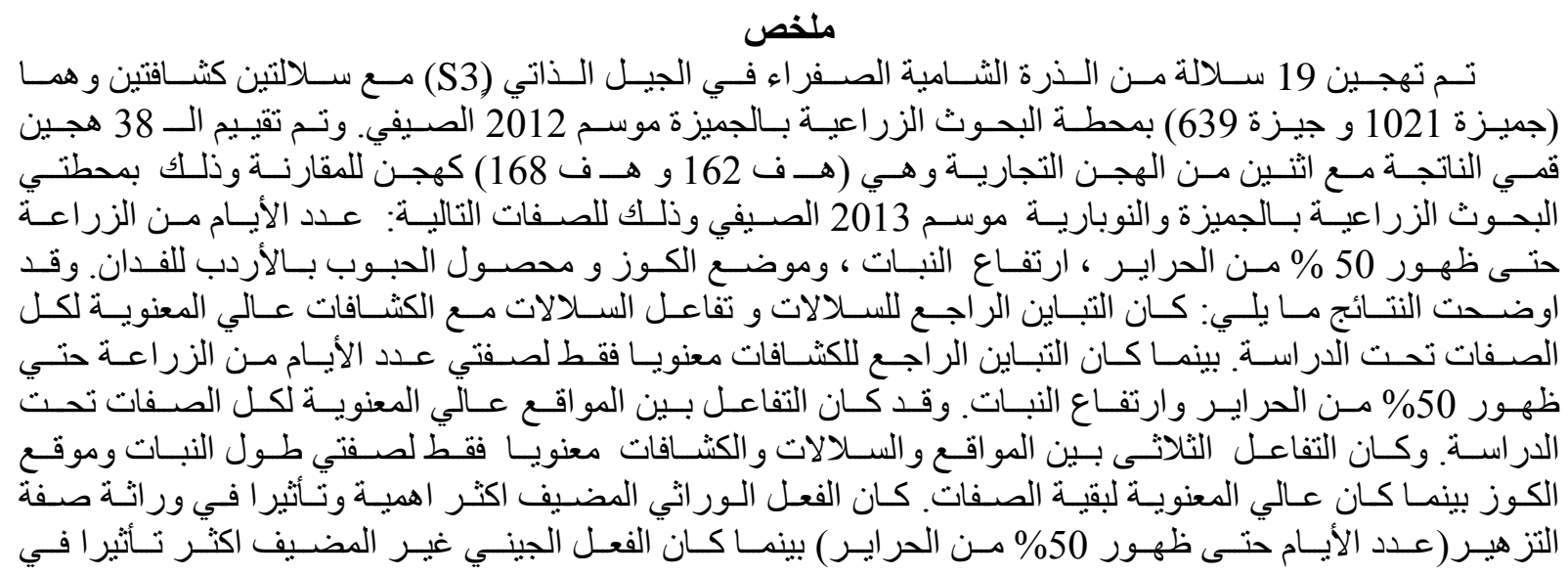




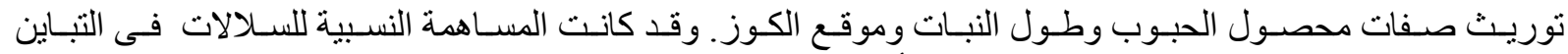

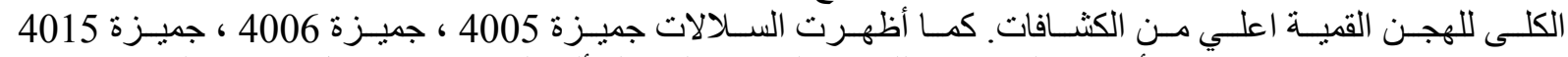

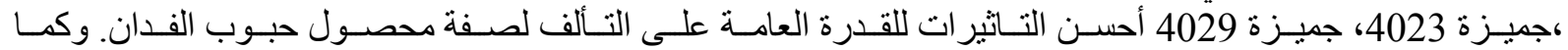

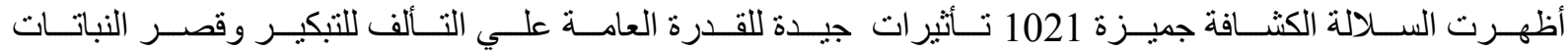

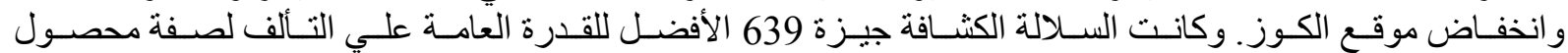

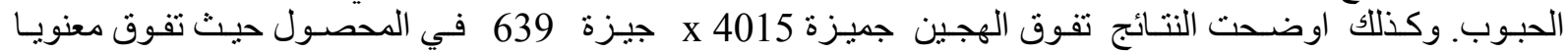

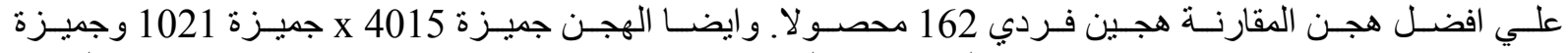

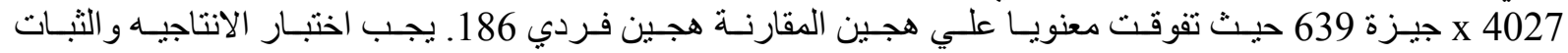

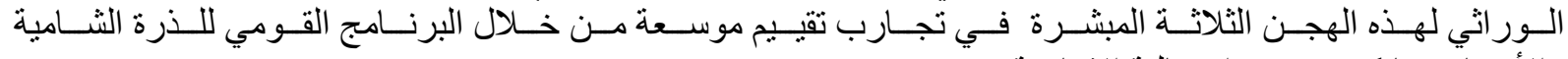
و الأستفادة بها كهجن صفر أه اله عالية الإنتاجية.

المجلة العمية لكلية الزراعة -جامعة القاهرة ـ المجلا (68) العدد الثانى (أبريل 2017 ) : 147-156. 